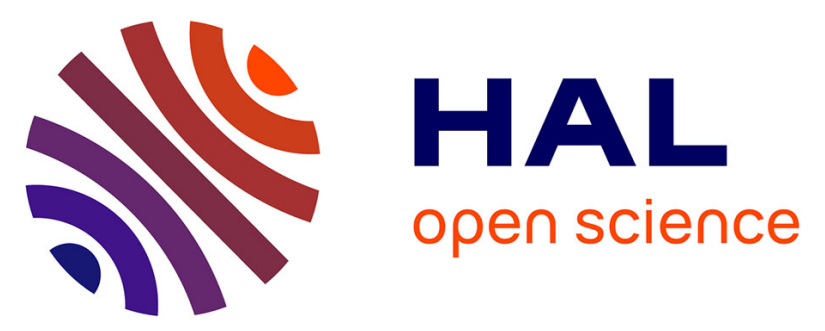

\title{
Hydrothermal fluid flow disruptions evidenced by subsurface changes in heat transfer modality: The La Fossa cone of Vulcano (Italy) case study
}

Tullio Ricci, Anthony Finizola, Stéphanie Barde-Cabusson, Eric Delcher, Salvatore Alparone, Salvatore Gambino, Vincenzo Milluzzo

\section{To cite this version:}

Tullio Ricci, Anthony Finizola, Stéphanie Barde-Cabusson, Eric Delcher, Salvatore Alparone, et al.. Hydrothermal fluid flow disruptions evidenced by subsurface changes in heat transfer modality: The La Fossa cone of Vulcano (Italy) case study. Geology, 2015, 43, pp.959-962. 10.1130/G37015.1 . hal-01390768

\section{HAL Id: hal-01390768 \\ https://hal.univ-reunion.fr/hal-01390768}

Submitted on 2 Nov 2016

HAL is a multi-disciplinary open access archive for the deposit and dissemination of scientific research documents, whether they are published or not. The documents may come from teaching and research institutions in France or abroad, or from public or private research centers.
L'archive ouverte pluridisciplinaire HAL, est destinée au dépôt et à la diffusion de documents scientifiques de niveau recherche, publiés ou non, émanant des établissements d'enseignement et de recherche français ou étrangers, des laboratoires publics ou privés. 


\title{
Hydrothermal fluid flow disruptions evidenced by subsurface changes in heat transfer modality: The La Fossa cone of Vulcano
} (Italy) case study

\author{
Tullio Ricci ${ }^{1}$, Anthony Finizola², Stéphanie Barde-Cabusson ${ }^{3}$, Eric Delcher ${ }^{2}$, Salvatore Alparone ${ }^{4}$, Salvatore Gambino ${ }^{4}$, \\ and Vincenzo Milluzzo 5 \\ 1 Istituto Nazionale di Geofisica e Vulcanologia, via di Vigna Murata 605, 00143 Rome, Italy \\ ¿Laboratoire GéoSciences Réunion, Université de la Réunion, Institut de Physique du Globe de Paris, Sorbonne Paris-Cité, CNRS \\ UMR 7154, 15 Avenue René Cassin, CS 92003, 97744, Saint-Denis, La Réunion, France \\ 3Instituto de Ciencias de la Tierra Jaume Almera-Consejo Superior de Investigaciones Científicas (ICTJA-CSIC), C/Lluís Solé i \\ Sabarís s/n, 08028 Barcelona, Spain \\ ${ }^{4}$ Istituto Nazionale di Geofisica e Vulcanologia, Osservatorio Etneo, Piazza Roma 2, 95125 Catania, Italy \\ ${ }^{5}$ Eni Angola, Avenida Lenine 58, Luanda, Angola
}

\section{ABSTRACT}

Detecting volcanic unrest is of primary importance for eruption forecasting, especially on volcanoes characterized by highly dangerous, and often seemingly unpredictable, phreatic or phreatomagmatic eruptions. We present a simple and innovative analysis of shallow vertical temperature profiles to depths of $70 \mathrm{~cm}$. These data were recorded at La Fossa cone of Vulcano (Aeolian Islands, Italy), during an episode of increased hydrothermal and seismic activities that occurred between September and December 2009. This work involves the use of the coefficient of determination $\left(R^{2}\right)$ on vertical temperature profiles in order to identify changes in conductive versus convective heat transfer modality. The increase in convective heat transfer can be related to the disruption of the hydrothermal system due to its pressurization and/or variation of ground permeability between the hydrothermal system and the surface. While raw temperature data do not evidence any significant variation during the period investigated and the classic temperature gradient is highly influenced by seasonal variations, the fluctuation of $\mathrm{R}^{2}$ displayed striking spikes that coincided with the seismic swarm inside the volcanic edifice. Such a low-cost device associated with easy real-time data processing could constitute a very promising, yet deceptively simple, technique to monitor hydrothermal systems, in order to assess the hazard posed by high-energy eruptions for populations living close to active volcanoes.

\section{INTRODUCTION}

Hydrothermal systems are characterized by important mass and energy transfer through the circulation of hot fluids underground that can be evidenced by geological, geophysical, or geochemical observations. One consequence of hydrothermal circulation is the alteration and weakening of the permeable ground inside volcanic edifices. Hydrothermal alteration greatly decreases the permeability of the medium and disrupts fluid circulation through self-sealing processes. Such modifications may increase pore pressure, the changes in which hydrothermal systems give an indication about the general state of volcanic unrest, and sometimes promote highly hazardous explosive phreatic or phreatomagmatic eruptions (Heiken et al., 1980; Barberi et al., 1992; Germanovich and Lowell, 1995; Ui et al., 2002; Starostin et al., 2005; Fournier and Chardot, 2012).

Studying variations in hydrothermal system activity is crucial to exploring their role in, and potential to forecast highly explosive activity. Therefore, identifying the key parameters that indirectly highlight the state of pressurization of the system is necessary to develop early warning of highly explosive eruptions. Temperature is perhaps the easiest and most obvious observable variable, and can be measured with soil temperature sensors, infrared cameras, or satellite-based multispectral infrared images (Gaudin et al., 2013).

Unfortunately, the change in temperature in hydrothermal system fluids is not an easy parameter to use in identifying precursors of volcanic unrest. Temperature is affected by many external parameters, such as daily and seasonal variations, rainfall, and wind speed and direction (Dawson and Fisher, 1964; Keszthelyi et al., 2003; Chiodini et al., 2005; Hochstein and Bromley, 2005; Peltier et al., 2012).

The aim of this paper is to propose an innovative method to process soil temperature time series that could be used in volcano observatories for real-time monitoring. This new technique can identify disruptions of hydrothermal fluid flow that potentially lead to volcanic unrest.

\section{APPLICATION SITE AND INSTRUMENTATION}

The test site where our temperature instrumentation was installed is La Fossa cone on Vulcano Island (Aeolian Islands, Italy), because of its persistent fumarolic activity, the presence of subfumarolic areas (documented in previous studies; e.g., Revil et al., 2008; Barde-Cabusson et al., 2009), and the recurrence of fumarolic crises during the past few decades (Chiodini et al., 1992; Granieri et al., 2006).

La Fossa cone, formed in the past 6 k.y. on the island of Vulcano, provides the historic basis for the term Vulcanian-type phreatomagmatic explosive eruptions, which are characterized by water-magma interaction (Frazzetta et al., 1983; Büttner et al., 1999; Dellino et al., 2011). The structure of the present-day edifice results from six main phases of activity (De Astis et al., 2006), chronologically associated with crater boundaries: (1) Punte Nere, (2) Palizzi, (3) Forgia Vecchia, (4) Pietre Cotte, and (5) Gran Cratere (Fig. 1A). Each of these structural boundaries is associated with relevant temperature anomalies identified through measurements at $30 \mathrm{~cm}$ depth (Revil et al., 2008; Barde-Cabusson et al., 2009), highlighting the major role of these crater ring faults in channeling hydrothermal fluids toward the surface.

Two sites of anomalous temperature were chosen for the installation of our instrumentation that correspond to two structural boundaries located outside the main fumarolic field of La Fossa crater (see Fig. 1A): (1) Gran Cratere (GC in Fig. 1A) and (2) Punte Nere (PN in Fig. 1A), located 250 $\mathrm{m}$ and $600 \mathrm{~m}$, respectively, from the last eruptive crater.

We used an Ebro Electronic EBI-2T type 313 data logger to monitor the temperature in the soil. The device temperature range is -40 to $+150{ }^{\circ} \mathrm{C}$, with 4 channels and 4 PT1000 sensors (resolution is $0.1{ }^{\circ} \mathrm{C}$ and measuring accuracy is $0.2{ }^{\circ} \mathrm{C}$ ). The temperature sensors were placed at the precise depths of 10, 30, 50, and $70 \mathrm{~cm}$ (see Fig. DR1 in the GSA Data Repository $\left.{ }^{1}\right)$ in areas where the soil temperature at $70 \mathrm{~cm}$ depth ranged between 70 and $80^{\circ} \mathrm{C}$. It is essential to avoid areas where the temperature signal is saturated by the buffering effect of steam present at boiling temperatures.

'GSA Data Repository item 2015319, temperature monitoring stations, seismicity related to fluid dynamics within the hydrothermal system of La Fossa cone of Vulcano, and heat transfer at shallow depth, is available online at www.geosociety .org/pubs/ft2015.htm, or on request from editing@geosociety.org or Documents Secretary, GSA, P.O. Box 9140, Boulder, CO 80301, USA. 
A

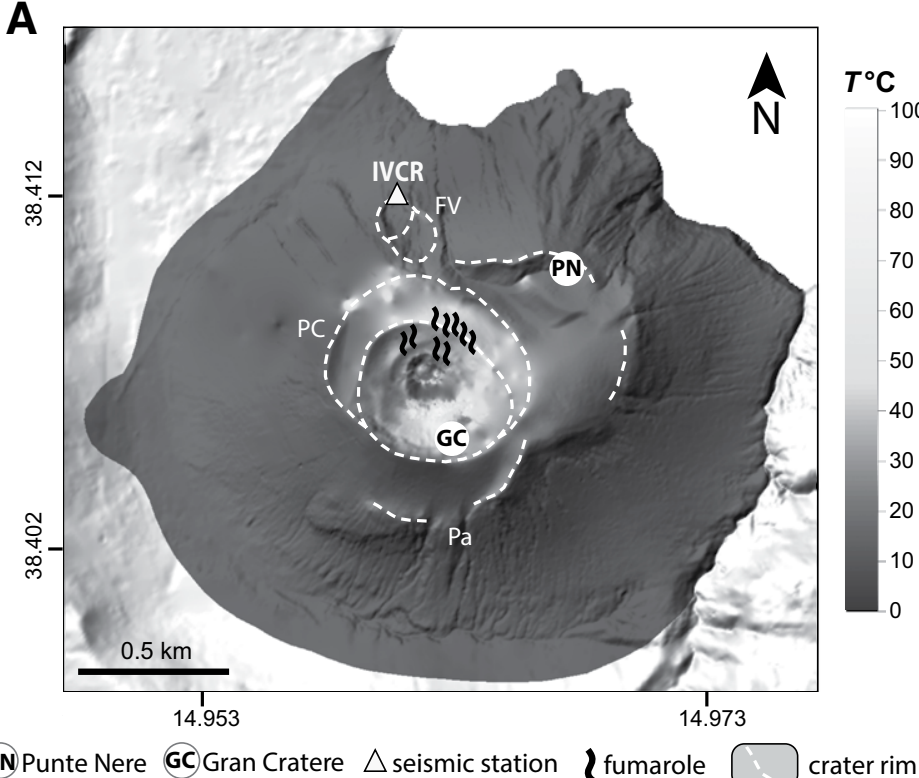

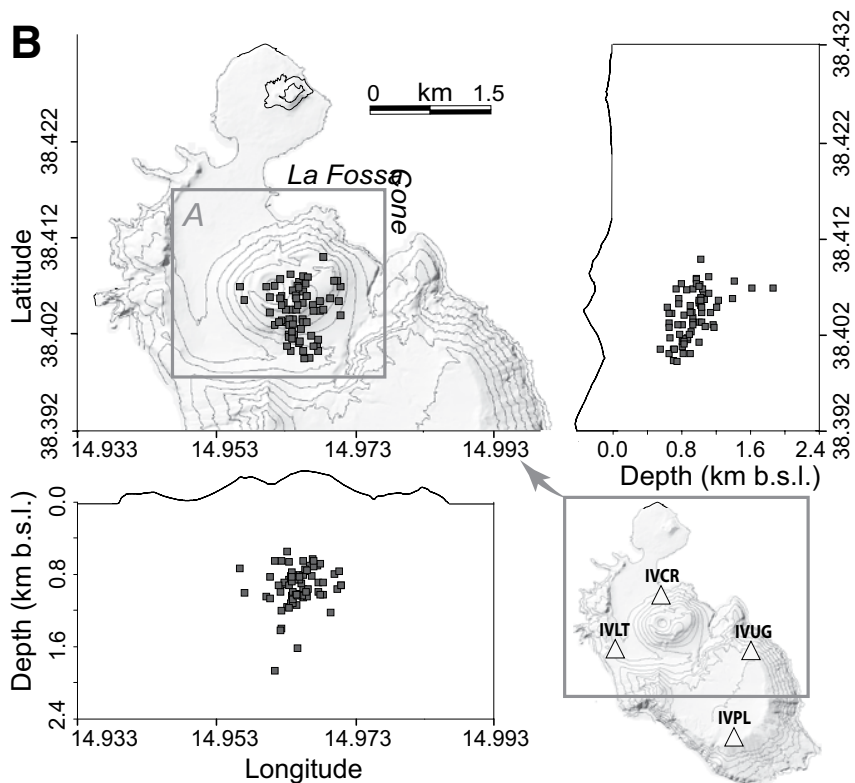

B

Longitude

Figure 1. Locations of crater boundaries, temperature data loggers, seismic network, and hypocenters of the 2009 seismic crisis at La Fossa cone (Vulcano, Aeolian Islands, Italy). A: Location of the two temperature data loggers over the soil temperature $(T)$ map (measured at 30 cm depth). Pa-Palizzi, FV-Forgia Vecchia, PC-Pietre Cotte, IVCR-location of the Istituto Nazionale di Geofisica e Vulcanologia (INGV) permanent seismic station at La Fossa cone. B: Location of INGV permanent seismic stations (triangles) operating at Vulcano Island, used to locate the hypocenters of the 2009 seismic crisis, and the seismic events (squares) during the 2009 seismic crisis at La Fossa cone (b.s.l.-below sea level).

Since its last magmatic eruption (A.D. 1888-1890), La Fossa crater has been affected by two main episodes of increased fumarolic activity and temperature. The first occurred during the period 1913-1923 (Sicardi, 1940), and the second began in 1978 after a M 5.5 earthquake (Chiodini et al., 1992). Relevant changes in the fumarolic composition occurred in 1979-1981, 1985, 1988, 1996, and in December 2004 and 2005 (Granieri et al., 2006; Carapezza et al., 2011).

At Vulcano, seismicity is associated with volcano-tectonic sources or is related to fluid dynamics within the hydrothermal system (Aubert et al., 2008; Cannata et al., 2012; Madonia et al., 2013). The first case is generally related to the north-northwest-south-southeast Tindari-Letojanni regional fault system dynamics (Gambino et al., 2012) and results in a few events per year, while the second comprises seismovolcanic events occurring in the hydrothermal system underlying La Fossa cone, from several hundred to thousands per year (Alparone et al., 2010; Milluzzo et al., 2010; see the Data Repository).

We compared seismic data with our results, because seismic swarms suggest the disruption of the hydrothermal system, an increase of the permeability inside the edifice, and consequently an increase of hot fluids flow toward the surface (Cannata et al., 2012; Milluzzo et al., 2010).

During our experiment, seismicity detected by the Istituto Nazionale di Geofisica e Vulcanologia seismic network (Fig. 1B) was characterized by a seismic swarm that occurred at shallow depth below La Fossa cone between 29 September and 16 December 2009 (Fig. 2E). During this seismic swarm, 3471 seismic events were detected in 79 days (an average of 43.9 events/day versus 11.2 events/day characterizing the period before the swarm). Due to the very low energy released, the identification of hypocenters was possible only for the $72(2.1 \%)$ most energetic seismic events, mainly located between 600 and $1200 \mathrm{~m}$ below sea level. In terms of number of events per day, this seismic swarm was the most important of the past two decades (Harris et al., 2012). At the same time, several geochemical parameters increased by one order of magnitude, such as soil $\mathrm{CO}_{2}$ flux and $\mathrm{SO}_{2}$ in the plume, indicating disruptions in the underlying magmatic system (Inguaggiato et al., 2012).

\section{RESULTS}

Raw data for soil temperature recorded at Gran Cratere (GC) and Punte Nere (PN) in the period 12 May 2009-28 July 2010 (Figs. 2A and $2 \mathrm{C}$ ) displayed, at both sites, a classic pattern of environmental temperature variations (periodic long-term seasonal variations, and short-term daily variations) disrupted by rainfall events. At the GC site, no temperature variation could be associated with the 2009 seismic swarm. At the PN site, however, only a weak variation of the signal coincided with changes in the seismicity, although there was no clear evidence to support this. In contrast, the temperature gradients calculated between 70 and $10 \mathrm{~cm}$ depths displayed a strong seasonality at both sites, preventing any possibility of clearly detecting disruptions related to hydrothermal activity (Figs. 2B and 2D). Despite the fact that we can note changes in the temperature gradient coinciding with variations of coefficient of determination, $\mathrm{R}^{2}$, at both sites, other changes of the same amplitude in the temperature gradient also appear outside the seismic swarm period. This means that changes in temperature gradient are not exclusively related to hydrothermal system disruptions, and they remain unclear due to a low signal-to-noise ratio.

In order to determine if the 2009 seismic swarm influenced the heat transfer modalities inside La Fossa cone, we computed a linear regression of temperature versus depth and $\mathrm{R}^{2}$ at each site and time interval. The aim of this analysis was to discriminate the conductive-dominated heat transfer from a more convective one (see the Data Repository); the former is characterized by a linear gradient of $\mathrm{R}^{2} \sim 1$, and the latter is characterized by a nonlinear gradient giving lower $\mathrm{R}^{2}$ values.

Applying an $\mathrm{R}^{2}$ analysis to our vertical temperature profiles (Figs. $2 \mathrm{~A}$ and $2 \mathrm{C}$ ), we obtained the results shown in Figures $2 \mathrm{~B}$ and 2D. At both GC and $\mathrm{PN}$ sites, significant anomalous spikes of $\mathrm{R}^{2}$ coincide with the seismic swarm, showing an obvious disruption in the hydrothermal fluid flow.

\section{DISCUSSION}

The comparison between the raw temperature data and the $\mathrm{R}^{2}$ variations obtained in the same data set displays striking results because no 


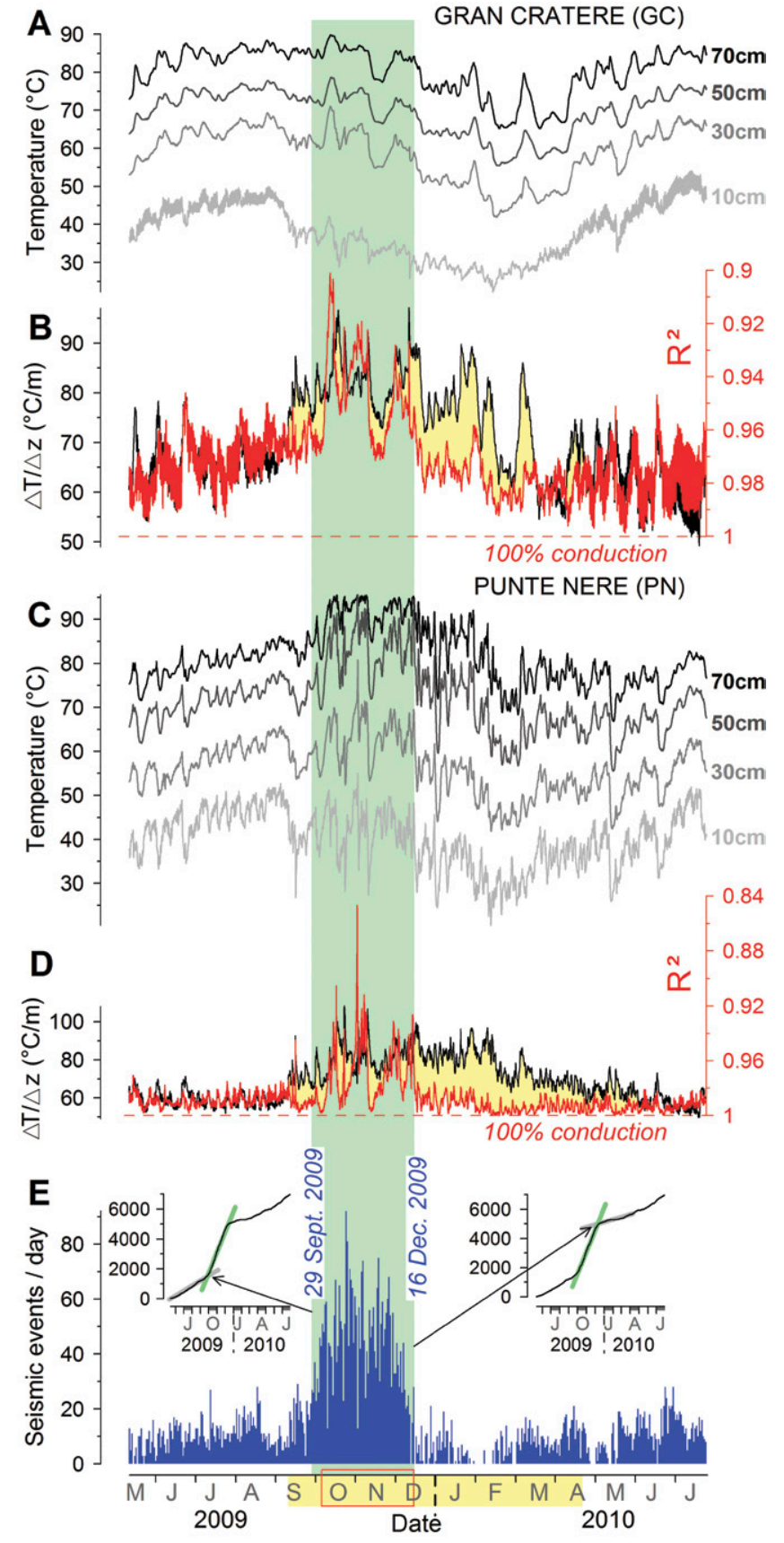

Figure 2. Temperature variations, coefficient of determination $\left(\mathbf{R}^{2}\right)$, and seismic events. A: Raw temperature data measured at 10, 30, 50 , and $70 \mathrm{~cm}$ depth at Gran Cratere (Vulcano, Aeolian Islands, Italy) during the period 12 May 2009-18 July 2010. B: Coefficient of determination (in red) and temperature gradient between 70 and $10 \mathrm{~cm}$ depth (in black and yellow) calculated on the temperature data set for the same period for Gran Cratere. $z$ is depth of temperature sensors. C: Temperature data measured at Punte Nere (Vulcano, Aeolian Islands, Italy). D: Coefficient of determination (in red) and temperature gradient between $\mathbf{7 0}$ and $\mathbf{1 0} \mathrm{cm}$ depth (in black and yellow) calculated on the temperature data set for the same period for Punte Nere. E: Number of seismic events recorded at the IVCR station, with the relative cumulative curves. Green area represents the period of seismic crisis evidenced by the cumulative curve of seismicity. The coefficient of determination allows distinguishing the evolution from a conductive to a convective heat transfer induced by a disruption of the hydrothermal system during the seismic crisis. temperature anomaly is obvious in the raw data during the period of seismic swarm. The main external parameters influencing the superficial soil temperature were daily and seasonal temperature variations and contrast between sunshine and cloudy periods. Each one of these parameters is related to pure heat conduction in the soil, and therefore exhibit $\mathrm{R}^{2} \sim 1$ despite substantial changes in temperature. These three external parameters have a different influence on temperature values measured by each individual sensor, as shown by the temperature gradient variations (Figs. 2B and 2D). Conversely, they do not significantly affect the heat transfer modality (conductive versus convective) of the heat toward the surface, driven mainly by the energy released at depth by the hydrothermal system. Although these external processes strongly modify the temperature values, they do not disrupt the linearity of the temperature gradient as a function of depth. In this sense, the $\mathrm{R}^{2}$ analysis constitutes an excellent filter for these external parameters and allows for extracting variations related to convective heat transfer of deep origin.

Rainfall is among the external parameters that influence temperature values. Rainfall corresponds to an injection of a cold fluid into the soil, which decreases the temperature and makes the top of the condensation zone deeper (see the Data Repository). As a consequence, the thickness of the conductive zone located above the condensation level increases, as well as $\mathrm{R}^{2}$. It can take from several days to a few weeks before a temperature disruption induced by a rainfall vanishes and the temperatures return to their initial values (Chiodini et al., 2005; Peltier et al., 2012). The duration of the disruption depends on the intensity of the rain and the geothermal energy released from the soil. Although rain events appear to have more significant consequences on the convective component, it is interesting to note that the external parameters previously described (seasonal and diurnal variations and strong sunshine periods) do not disrupt the signal toward a more convective end member. Therefore, a decrease of $\mathrm{R}^{2}$ is basically the result of an increase in the advective hydrothermal fluid flow toward the surface.

Moreover, unlike remote techniques used for temperature detection (e.g., infrared camera or infrared channels of satellite images), cloudy weather has no adverse effect on the acquisition of soil temperature data, representing a real advantage in thermal monitoring of active volcanoes.

The seismic swarm began 9 days before the decrease of $\mathrm{R}^{2}$ values, on 29 September and 8 October, respectively. This time delay suggests that the disruption of the hydrothermal fluid flow at the surface could be a consequence of the seismic swarm. Small perturbations temporarily increasing the pore pressure can modify the effective normal stress and trigger seismicity. This phenomenon and other fracturing processes (due to alteration of rock to secondary minerals by reducing the shear stress required to initiate fracturing and/or increases in temperatures in the rock and consequent rock fracturing) are also able to enhance the rock's vertical permeability, thus favoring the rise of fluids (Cannata et al., 2012, and references therein).

\section{CONCLUSIONS}

Our results indicate that monitoring the linearity of the vertical temperature profiles at shallow depths (to $70 \mathrm{~cm}$ ), and therefore the changes from conductive to convective heat transfer in the near surface, is an efficient tool for the identification of volcanic unrest associated with disruption of a hydrothermal system. The installation of such a simple temperature monitoring device could be considered by volcano observatories because it gives fundamental information on changes of heat transfer modality not highlighted by ordinary thermal monitoring. Moreover, data processing can be easily integrated into a real-time monitoring for surveillance purposes. An increase of the hydrothermal activity can be related to pressure and/or permeability changes inside the edifice, potentially leading to explosive activity. Such information is of prime importance for eruption forecasting and hazard assessment and, ultimately, volcanic risk mitigation. 


\section{ACKNOWLEDGMENTS}

This work has been supported by the University of La Réunion-Institut de Physique du Globe de Paris (IPGP) and the CNRS-INSU (Centre National de la Recherche Scientifique, Institut National des Sciences de l'Univers) project, and a one-month IPGP (Institut de Physique du Globe de Paris) Invited Researcher program for Ricci in the Laboratoire GéoSciences Réunion. Barde-Cabusson was funded by the Spanish National Research Council JAE-Doc (Junta para la Ampliación de Estudios) Program (JAEDoc_09_01319). We thank B. Suski and M.S. Davis for constructive comments concerning the manuscript, and U. Sistometro for field assistance. Comments from reviewers N. Fournier, D. Hasterok, and G. Chiodini greatly improved the manuscript. This is IPGP contribution 3524. Data are available from the authors upon request.

\section{REFERENCES CITED}

Alparone, S., Cannata, A., Gambino, S., Gresta, S., Milluzzo, V., and Montalto, P., 2010, Time-space variation of volcano-seismic events at La Fossa (Vulcano, Aeolian Islands, Italy): New insights into seismic sources in a hydrothermal system: Bulletin of Volcanology, v. 72, p. 803-816, doi:10.1007 Is00445-010-0367-6.

Aubert, M., Diliberto, S., Finizola, A., and Chébli, Y., 2008, Double origin of hydrothermal convective flux variations in the Fossa of Vulcano (Italy): Bulletin of Volcanology, v. 70, p. 743-751, doi:10.1007/s00445-007-0165-y.

Barberi, F., Bertagnini, A., Landi, P., and Principe, C., 1992, A review on phreatic eruptions and their precursors: Journal of Volcanology and Geothermal Research, v. 52, p. 231-246, doi:10.1016/0377-0273(92)90046-G.

Barde-Cabusson, S., et al., 2009, New geological insights and structural control on fluid circulation in La Fossa cone (Vulcano, Aeolian Islands, Italy): Journal of Volcanology and Geothermal Research, v. 185, p. 231-245, doi: 10.1016/j.jvolgeores.2009.06.002.

Büttner, R., Dellino, P., and Zimanowski, B., 1999, Identifying magma-water interaction from the surface features of ash particles: Nature, v. 401, p. 688690, doi:10.1038/44364.

Cannata, A., Diliberto, I.S., Alparone, S., Gambino, S., Gresta, S., Liotta, M., Madonia, P., Milluzzo, V., Aliotta, M., and Montalto, P., 2012, Multiparametric approach in investigating hydrothermal systems: The case of study of Vulcano (Aeolian Islands, Italy): Pure and Applied Geophysics, v. 169, p. 167-182, doi:10.1007/s00024-011-0297-z.

Carapezza, M.L., et al., 2011, Diffuse $\mathrm{CO}_{2}$ soil degassing and $\mathrm{CO}_{2}$ and $\mathrm{H}_{2} \mathrm{~S}$ air concentration and related hazard at Vulcano Island (Aeolian arc, Italy): Journal of Volcanology and Geothermal Research, v. 207, p. 130-144, doi: 10.1016/j.jvolgeores.2011.06.010.

Chiodini, G., Cioni, R., Falsaperla, S., Montalto, A., Guidi, M., and Marini, L., 1992, Geochemical and seismological investigations at Vulcano (Aeolian Islands) during 1978-1989: Journal of Geophysical Research, v. 97, no. B7, p. 11,025-11,032, doi:10.1029/92JB00518.

Chiodini, G., Granieri, D., Avino, R., Caliro, S., Costa, A., and Werner, C., 2005, Carbon dioxide diffuse degassing and estimation of heat release from volcanic and hydrothermal systems: Journal of Geophysical Research, v. 110, B08204, doi:10.1029/2004JB003542.

Dawson, G.B., and Fisher, R.G., 1964, Diurnal and seasonal ground temperature variations at Wairakei: New Zealand Journal of Geology and Geophysics, v. 7, p. 144-154, doi:10.1080/00288306.1964.10420166.

De Astis, G., Dellino, P., La Volpe, L., Lucchi, F., and Tranne, C.A., 2006, Geological map of the Vulcano Island: Florence, Italy, Litografia Artistica Cartografica, scale 1:10,000.

Dellino, P., De Astis, G., La Volpe, L., Mele, D., and Sulpizio, R., 2011, Quantitative hazard assessment of phreatomagmatic eruptions at Vulcano (Aeolian Islands, Southern Italy) as obtained by combining stratigraphy, event statistics and physical modeling: Journal of Volcanology and Geothermal Research, v. 201, p. 364-384, doi:10.1016/j.jvolgeores.2010.06.009.

Fournier, N., and Chardot, L., 2012, Understanding volcano hydrothermal unrest from geodetic observations: Insights from numerical modeling and application to White Island volcano, New Zealand: Journal of Geophysical Research, v. 117, B11208, doi:10.1029/2012JB009469.

Frazzetta, G., La Volpe, L., and Sheridan, M.F., 1983, Evolution of the Fossa cone, Vulcano: Journal of Volcanology and Geothermal Research, v. 17, p. 329-360, doi:10.1016/0377-0273(83)90075-6.
Gambino, S., Milluzzo, V., Scaltrito, A., and Scarfi, L., 2012, Relocation and focal mechanisms of earthquakes in the south-central sector of the Aeolian Archipelago: New structural and volcanological insights: Tectonophysics, v. 524, p. 108-115, doi:10.1016/j.tecto.2011.12.024.

Gaudin, D., Beauducel, F., Allemand, P., Delacourt, C., and Finizola, A., 2013, Heat flux measurement from thermal infrared imagery in low-flux fumarolic zone: Example of the Ty fault (La Soufrière de Guadeloupe): Journal of Volcanology and Geothermal Research, v. 267, p. 47-56, doi:10.1016/j .jvolgeores.2013.09.009.

Germanovich, L.N., and Lowell, R.P., 1995, The mechanism of phreatic eruptions: Journal of Geophysical Research, v. 100, no. B5, p. 8417-8434, doi:10.1029 194JB03096.

Granieri, D., Carapezza, M.L., Chiodini, G., Avino, R., Caliro, S., Ranaldi, M., Ricci, T., and Tarchini, L., 2006, Correlated increase in $\mathrm{CO}_{2}$ fumarolic content and diffuse emission from la Fossa crater (Vulcano, Italy): Evidence of volcanic unrest or increasing gas release from a stationary deep magma body?: Geophysical Research Letters, v. 33, L13316, doi:10.1029/2006GL026460.

Harris, A., Alparone, S., Bonforte, A., Dehn, J., Gambino, S., Lodato, L., and Spampinato, L., 2012, Vent temperature trends at the Vulcano Fossa fumarole field: The role of permeability: Bulletin of Volcanology, v. 74, p. 1293 1311, doi:10.1007/s00445-012-0593-1.

Heiken, G., Crowe, B., McGetchin, T., West, F., Eichelberger, J., Bartram, D., Peterson, R., and Wohletz, K., 1980, Phreatic eruption clouds: The activity of La Soufrière de Guadeloupe, F.W.I., August-October, 1976: Bulletin of Volcanology, v. 43, p. 383-395, doi:10.1007/BF02598039.

Hochstein, M.P., and Bromley, C.J., 2005, Measurement of heat flux from steaming ground: Geothermics, v. 34, p. 131-158, doi:10.1016/j.geothermics.2004 .04 .002 .

Inguaggiato, S., Calderone, L., Inguaggiato, C., Mazot, A., Morici, S., and Vita, F., 2012, Long-time variation of soil $\mathrm{CO}_{2}$ fluxes at the summit crater of Vulcano (Italy): Bulletin of Volcanology, v. 74, p. 1859-1863, doi:10.1007 /s00445-012-0637-6.

Keszthelyi, L., Harris, A.J.L., and Dehn, J., 2003, Observations of the effect of wind on the cooling of active lava flows: Geophysical Research Letters, v. 30, 1989, doi:10.1029/2003GL017994.

Madonia, P., Cusano, P., Diliberto, I.S., and Cangemi, M., 2013, Thermal anomalies in fumaroles at Vulcano island (Italy) and their relationship with seismic activity: Physics and Chemistry of the Earth, v. 63, p. 160-169, doi:10.1016 /j.pce.2013.06.001.

Milluzzo, V., et al., 2010, Tornillos at Vulcano: Clues to the dynamics of the hydrothermal system: Journal of Volcanology and Geothermal Research, v. 198, p. 377-393, doi:10.1016/j.jvolgeores.2010.09.022.

Peltier, A., Finizola, A., Douillet, G., Brothelande, E., and Garaebiti, E., 2012, Structure of an active volcano associated with a resurgent block inferred from thermal mapping: The Yasur-Yenkahe volcanic complex (Vanuatu): Journal of Volcanology and Geothermal Research, v. 243-244, p. 59-68, doi: 10.1016/j.jvolgeores.2012.06.022.

Revil, A., et al., 2008, Inner structure of La Fossa di Vulcano (Vulcano Island, southern Tyrrhenian Sea, Italy) revealed by high-resolution electric resistivity tomography coupled with self-potential, temperature, and $\mathrm{CO}_{2}$ diffuse degassing measurements: Journal of Geophysical Research, v. 113, B07207, doi: $10.1029 / 2007 J B 005394$.

Sicardi, L., 1940, Il recente ciclo dell'attività fumarolica dell'isola di Vulcano: Bulletin of Volcanology, v. 7, p. 85-139, doi:10.1007/BF02994895.

Starostin, A.B., Barmin, A.A., and Melnik, O.E., 2005, A transient model for explosive and phreatomagmatic eruptions: Journal of Volcanology and Geothermal Research, v. 143, p. 133-151, doi:10.1016/j.jvolgeores.2004.09.014.

Ui, T., Nakagawa, M., Inaba, C., Yoshimoto, M., Hayashi, S., and the Geological Party Joint Research Group for the Usu 2000 Eruption, 2002, Sequence of the 2000 eruption, Usu volcano: Volcanological Society of Japan Bulletin, v. 47 , p. $105-117$. 